\title{
Prevalence and clinical significance of incidental extracardiac findings in cardiac magnetic resonance imaging
}

\author{
Narumol Chaosuwannakit ${ }^{1}$, Pattarapong Makarawate ${ }^{2}$ \\ ${ }^{1}$ Radiology Department, Khon Kaen University, Khon Kaen, Thailand \\ ${ }^{2}$ Department of Internal Medicine, Faculty of Medicine, Khon Kaen University, Khon Kaen, Thailand
}

Kardiochirurgia i Torakochirurgia Polska 2018; 15 (4): 241-245

\begin{abstract}
Introduction: Incidental pathological findings are frequently found outside the investigated cardiovascular system in cardiac magnetic resonance (CMR) imaging. Some of these findings might have clinical importance.

Aim: To evaluate the prevalence and significance of extracardiac findings (ECFs) in patients referred for CMR. The CMR has the ability to depict ECFs in the visualized thorax and upper abdomen. These incidental lesions can often present a challenge to physicians.

Material and methods: A total of 192 CMR reports were retrospectively reviewed for extracardiac findings. ECFs were classified as benign, indeterminate, or of clinical significance at the time of image evaluation. Benign findings were those considered to be of little clinical significance with no followup needed. Indeterminate findings were those deemed of potential clinical importance, requiring correlation of the patient history or a follow-up study. Clinically significant findings were those felt to be of definite clinical importance requiring immediate evaluation or intervention.

Results: A total of 56 (29.2\%) ECFs were found in 192 (29.2\%) patients. Of those, 21 (37.5\%) were considered benign, 23 (41\%) indeterminate, and 12 (21.4\%) clinically significant findings. In the clinically significant group, the most common findings were liver and pulmonary masses. Five malignancies were observed with certainty at CMR. All of them had been incidentally diagnosed on CMR for the first time, and the patients' management was subsequently changed.

Conclusions: Extracardiac findings in clinically indicated CMR are common in the present study (about 29.2\%). Radiologists and cardiologists should be aware of relevant extracardiac findings that might require additional diagnostics or treatment.
\end{abstract}

Key words: extracardiac findings, cardiac magnetic resonance imaging.

\section{Streszczenie}

Cel: Ocena występowania i znaczenia przypadkowych znalezisk pozakardiologicznych (ECF) u pacjentów skierowanych na badanie rezonansu magnetycznego serca (CMR). Badanie CMR umożliwia wykrycie zmian pozakardiologicznych w klatce piersiowej i górnej części jamy brzusznej. Zmiany te często stanowią wyzwanie dla lekarzy.

Materiał i metody: Badaniu retrospektywnemu poddano ogółem 192 obrazy CMR pod kątem zmian pozakardiologicznych. Zmiany te klasyfikowano jako łagodne, nieokreślone lub istotne klinicznie w czasie oceny. Zmiany łagodne to zmiany o niewielkiej istotności klinicznej, niewymagajace obserwacji. Zmianami nieokreślonymi nazywa się zmiany potencjalnie istotne klinicznie, które wymagają zestawienia z historią pacjenta lub obserwacji, natomiast istotnymi klinicznie - zmiany, które mają określone znaczenie kliniczne i wymagają natychmiastowej oceny lub interwencji.

Wyniki: Stwierdzono ogółem 56 (29,2\%) zmian pozakardiologicznych u 192 pacjentów, z czego 21 (37,5\%) uznano za łagodne, 23 (41\%) - nieokreślone, a 12 (21,4\%) - klinicznie istotne. W grupie zmian klinicznie istotnych najczęściej obserwowano masy w wątrobie lub płucach. W badaniu CMR odnotowano 5 guzów. Wszystkie guzy były zdiagnozowane przypadkowo w pierwszym badaniu CMR, a leczenie pacjentów zostało następnie zmienione.

Wnioski: Zmiany pozakardiologiczne stwierdzone w badaniach CMR są częstym zjawiskiem (ok. 29,2\%). Radiolodzy i kardiolodzy powinni wiedzieć o ważnych zmianach pozakardiologicznych, które mogą wymagać podjęcia dodatkowej diagnostyki lub leczenia.

Słowa kluczowe: zmiany pozakardiologiczne, rezonans magnetyczny serca.

Address for correspondence: Narumol Chaosuwannakit MD, FSCMR, Radiology Department, Faculty of Medicine, Khon Kaen University, 40002 Khon Kaen, Thailand, e-mail: narumol_chao@yahoo.com

Received: 27.08.2018, accepted: 11.11.2018. 


\section{Introduction}

Cardiac and cardiovascular magnetic resonance imaging (CMR) is increasingly used to visualize and evaluate the cardiovascular system [1-4]. Although the key components of a CMR study are acquired in specific imaging planes orientated along the axes of the heart, initial axial and occasionally coronal images of the thorax and upper abdomen are also acquired to help plan the study. Wide spatial coverage of this imaging technique, capturing anatomical regions of the thoracic and upper abdominal cavity, may lead to incidental pathological findings outside the investigated cardiovascular system. Some of these extracardiac findings (ECFs) might have clinical implications including resulting in a new diagnosis, leading to further investigations or requiring early treatment.

\section{Aim}

This study aimed to determine the prevalence of extracardiac finding in a clinically indicated CMR and their clinical significance by reviewing how they reflect the subsequent diagnosis, further investigations and treatment plan of the patient.

\section{Material and methods}

The study retrospectively analyzed the clinically indicated CMR performed at a single academic hospital from January 1, 2014 to December, 2017. In total, 192 clinical CMR reports were reviewed. This study was performed in accordance with the regulations of the local ethics committee.

\section{Cardiovascular magnetic resonance acquisition}

Cardiovascular magnetic resonances were performed on a 1.5 T Siemens Avanto system (Siemens Medical Solutions, Erlangen, Germany) following a standard protocol. The CMR study protocols varied according to the specific clinical indications and adhered to standards published in the literature [5]. Basically, all CMR studies were done using electrocardiogram (ECG) gating or ECG trigger. After a set of localizers, half-Fourier acquisition single shot turbo spin echo (HASTE) as well as steady-state free precession (SSFP) sequences were used to cover an anatomical range from the thyroid down to the upper abdomen, laterally including both axillas. Imaging planes applied were axial, coronal, and sometimes sagittal. Slice thickness was kept between 6 and $8 \mathrm{~mm}$ without a gap for all anatomical imaging sequences. These anatomical sequences were most important for the assessment of extracardiac findings, since they provided the largest anatomical coverage among all imaging sequences of the cardiac magnetic resonance imaging (MRI) examination. Specific cardiac axes were covered by standard breath-hold cine SSFP sequences. If applicable, multislice SSFP-perfusion sequences were used during adenosine-infusion for diagnosis of ischemia; T1 dark blood SE, double inversion recovery T2-weighted imaging as well as early enhancement imaging were ap- plied if necessary; late enhancement imaging was done in almost all cases, replicating exactly the same imaging planes from the cine SSFP sequences. When applicable, Gd-based contrast medium was used (including spin echo black blood coronal and axial sequences: short axis, four chamber and three chamber views, myocardial perfusion sequence and delayed contrast enhancement sequences). Images were reviewed using a PACS system.

\section{Cardiovascular magnetic resonance image interpretation and follow-up}

Each CMR examination was retrospectively reviewed by an experienced radiologist and cardiologist in consensus and the incidental extracardiac findings were reported. They were blinded for any information. The follow-up period was about 3 years in the first and 4 months in the last CMR scan. Follow-up included searching for additional imaging, continuing the patient's history, and collecting pathological or histological reports after surgical or interventional procedures. Patient characteristics were analyzed and summarized.

The ECFs were subdivided as thoracic when located above the diaphragm and abdominal when located below the diaphragm. The ECFs were also classified according to their clinical significance as severe, indeterminate, and mild. A similar classification system was used as in several cardiac MDCT and CMR studies before [6-10].

Severe findings were those of definite clinical importance, requiring immediate evaluation or intervention. Indeterminate findings were those of potential clinical importance, requiring a follow-up study or correlation with the patient's history. Finally, mild findings were those considered to be of little clinical significance with no further need of follow-up.

To assess the clinical implications of extracardiac finding, follow-up data were analyzed by reviewing the electronic medical records database of the hospital. According to the follow-up data, extracardiac finding (for which data were available) were classified as clinically significant or insignificant.

\section{Statistical analysis}

Statistical analysis was performed with commercially available software (SPSS Inc., version 18.0, Chicago, IL, USA). Averages are presented with 1 standard deviation (SD). Continuous variables were reported as mean \pm standard deviation or median and interquartile range, dichotomous as percentages.

\section{Results}

\section{Patient characteristics}

Within the study period 192 clinically indicated CMR were consecutively performed and retrospectively reviewed for this study. All patients were studied, including young patients (e.g., children with congenital heart disease) and elderly patients (e.g., with CMR for detection of myocardial 
ischemia and scars). Clinical characteristics of the patients are summarized in Table I.

\section{Prevalence}

A total of total of 192 CMR cases were retrospectively reviewed including 121 men and 71 women (age range from 5 to 88 , mean age: $50.2 \pm 12.1$ years). A total of 56 ECFs $(29.2 \%)$ were found: 21 (37.5\%) were classified as mild, $23(41.1 \%)$ as indeterminate and $12(21.4 \%)$ as severe. The mild findings were $47.6 \%$ (10 of 21 ) thoracic and $52.4 \%$ (11 of 21) abdominal, while indeterminate findings were $87 \%$ (20 of 23) thoracic and 13\% (3 of 23) abdominal. Lastly, the severe findings were $58.3 \%$ (7 of 12) thoracic and $41.7 \%$ (5 of 12) abdominal. Mild abdominal findings included renal cyst or liver cyst (Table II). Mild thoracic findings included healed rib fracture and extramedullary hematopoiesis (Fig. 1). The indeterminate abdominal finding were ascites and hiatal hernia (Fig. 2). Indeterminate thoracic findings included pulmonary nodules $>0.8 \mathrm{~cm}$ and $<3 \mathrm{~cm}$, lymphadenopathy, pleural effusion, consolidation, and pleural thickening (Table III). Severe abdominal findings included liver mass and renal mass (Table IV). Severe thoracic findings included pulmonary nodules $>3 \mathrm{~cm}$, an ascending aortic aneurysm, aortic dissection, and pulmonary embolism (Fig. 3). In 2 patients, pulmonary nodules classified as indeterminate were known from previous thorax computed tomography (CT) examinations. No change in size was detected within 2 or more years and the nodules were considered mild. For the indeterminate and severe pulmonary nodules, either a follow-up with CT or further evaluation by biopsy was recommended. A pathological verification was available for 2 of the 3 pulmonary nodules $>3 \mathrm{~cm}$, which proved to be malignant. The patients with consolidation received antibiotic therapy $(n=2)$. A follow-up with CT chest showed regression of the lung lesions. Eight patients with pleural effusions had a known history of congestive heart failure and the effusions existed in recent previous chest radio-
Table I. Patient characteristics $(n=192)$

\begin{tabular}{lc} 
Parameter & Value \\
Age, mean \pm SD (range) [years] & $50.2 \pm 12.1(5-88)$ \\
\hline Men & $121(63 \%)$ \\
\hline Height, mean \pm SD $[\mathrm{cm}]$ & $160.9 \pm 15$ \\
\hline Weight, mean \pm SD $[\mathrm{kg}]$ & $56.2 \pm 12$ \\
\hline Body mass index, mean \pm SD (range) $\left[\mathrm{kg} / \mathrm{m}^{2}\right]$ & $24.2 \pm 8(18-36)$ \\
\hline Diabetes mellitus & $65(34 \%)$ \\
\hline Hypertension* $^{*}$ & $98(51 \%)$ \\
\hline Hypercholesterolemia** $^{*}$ & $72(38 \%)$ \\
\hline Current smoker $^{*}$ & $21(11 \%)$ \\
\hline Obesity $^{\star *}$ & $5(3 \%)$ \\
\hline
\end{tabular}

*Blood pressure $>140 / 90 \mathrm{~mm} \mathrm{Hg}$ or treatment for hypertension. **Total cholesterol $>180 \mathrm{mg} /$ dl or treatment for hypercholesterolemia. ${ }^{* * *}$ Body mass index $>30 \mathrm{~kg} / \mathrm{m}^{2}$.

Table II. Classification of mild incidental non-cardiac abnormal findings according to location

\begin{tabular}{lc} 
Parameter & Value \\
\hline Abdomen: & 11 \\
\hline Liver cyst & 5 \\
\hline Renal cyst & 6 \\
\hline Thorax: & 10 \\
\hline Extramedullary hematopoiesis & 3 \\
\hline Healed rib fracture & 7
\end{tabular}

graphs. A patient with pulmonary emboli received anticoagulant therapy.

\section{Discussion}

In the present study, we found extracardiac findings in $29.2 \%$ of CMR. Approximately a quarter of ECF were clinically significant in the follow-up with an overall prevalence in CMR of $1.3 \%$. The majority of incidental findings are clinically irrelevant or insignificant with anatomical varia-
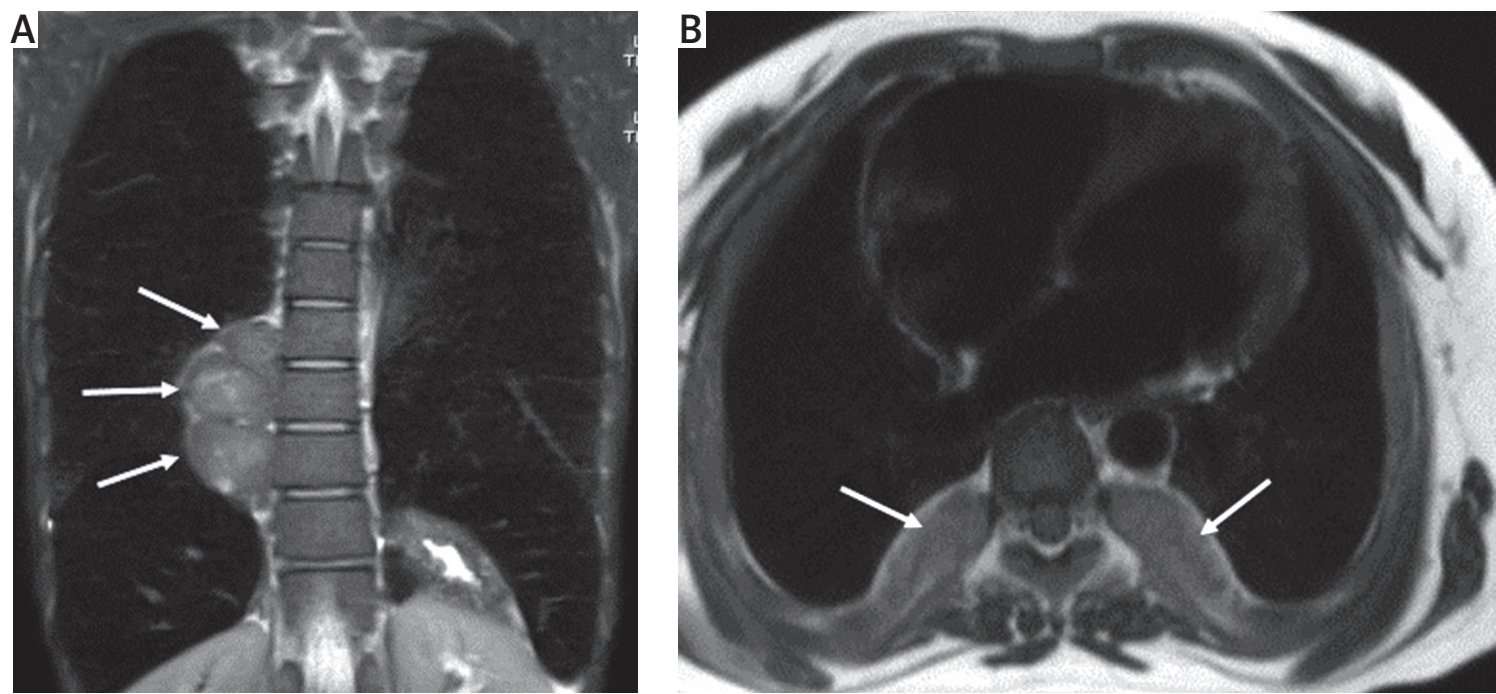

Fig. 1. Incidentally detected extramedullary hematopoiesis in a 12-year-old thalassemia patient. Coronal (A) and axial (B) black blood half-Fourier acquisition single shot turbo spin echo (HASTE) images showed bilateral paravertebral masses (arrows) 

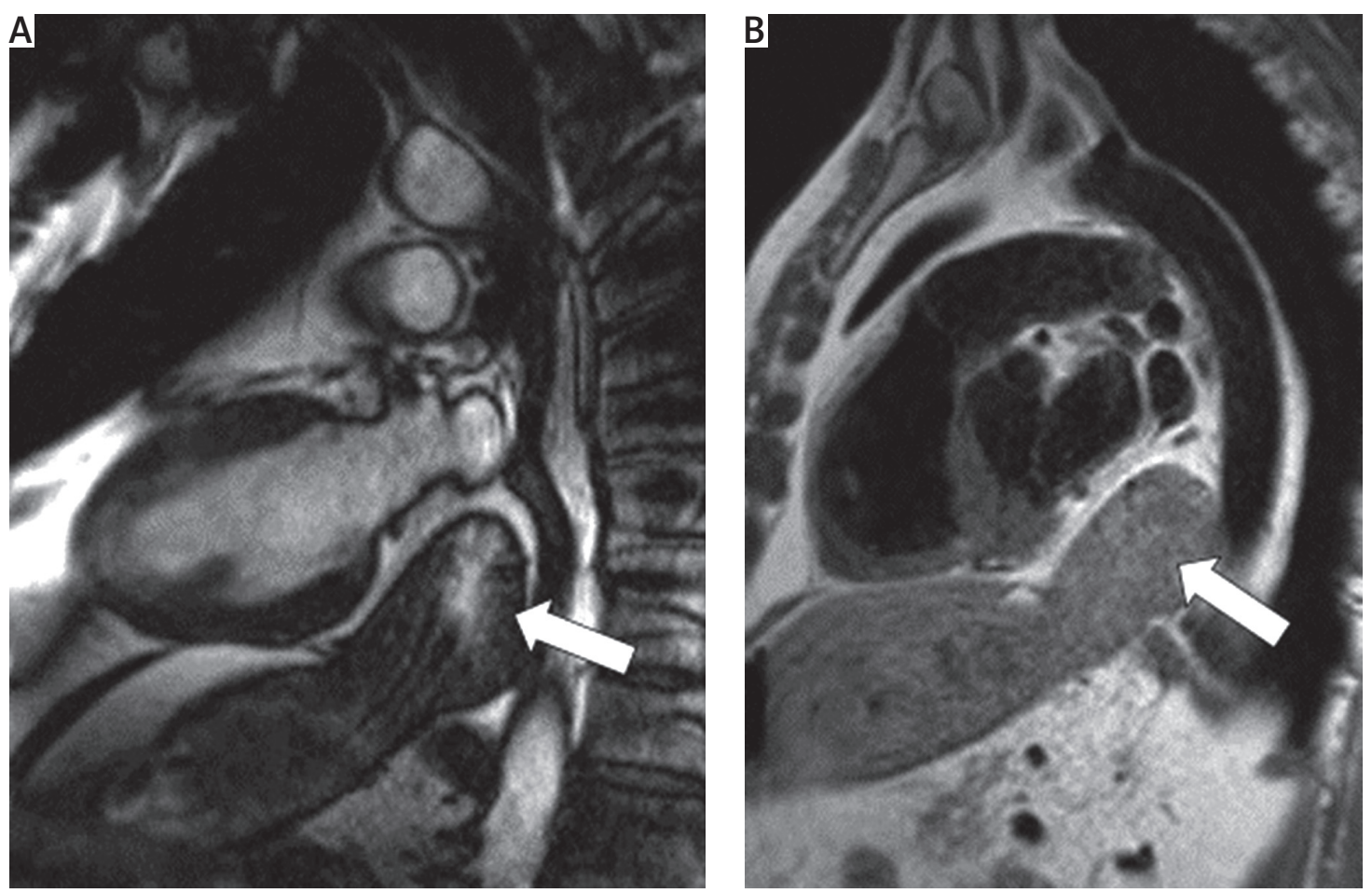

Fig. 2. A, B - Hiatal hernia incidentally found in a 72-year-old man

tions or benign minor changes, such as simple cysts. Early treatment of such incidental pathologies (e.g. early stage kidney or lung tumor) might prevent their progression and

Table III. Classification of indeterminate incidental non-cardiac abnormal findings according to location

\begin{tabular}{ll} 
Parameter & Value \\
\hline Abdomen: & 3 \\
\hline Ascites & 2 \\
\hline Hiatal hernia & 1 \\
\hline Thorax: & 20 \\
\hline Pulmonary nodule $>0.8 \mathrm{~cm}$ and $<3 \mathrm{~cm}$ & 2 \\
\hline Lymphadenopathy & 7 \\
\hline Pleural effusion & 8 \\
\hline Consolidation & 2 \\
\hline Pleural thickening & 1 \\
\hline
\end{tabular}

Table IV. Classification of severe incidental non-cardiac abnormal findings according to location

\begin{tabular}{ll} 
Parameter & Value \\
\hline Abdomen: & 5 \\
\hline Liver mass & 4 \\
\hline Renal mass & 1 \\
\hline Thorax: & 7 \\
\hline Pulmonary nodule > $3 \mathrm{~cm}$ & 3 \\
\hline Pulmonary embolism & 1 \\
\hline Aortic dissection & 1 \\
\hline Ascending thoracic aortic aneurysm & 2 \\
\hline
\end{tabular}

complications and eventually lead to better outcomes. On the other hand, further investigation of an incidental benign finding might be redundant and survival might not be improved [11]. Therefore, it is important to discriminate between clinically significant and insignificant ECF and to decide which should be treated and which could be left alone. Atalay et al. [10] reported an ECF rate of $27 \%$ compared to $29.2 \%$ in our study. This rate is similar to our result, as the study designs were quite similar. Khosa et al. found 33\% ECF prevalence with a second revision of clinically indicated CMR [11]. In the present study, we did not have information on whether ECF was previously known. However, even when a finding is already known, additional incidental imaging may be valuable as a follow-up opportunity. Changes or persistence of the incidentally found pathology may provide important information, helping to decide not to treat a patient unnecessarily. We consider that the best approach is to view all available data in each CMR study, report all non-cardiac findings estimating their clinical significance, and consult each patient appropriately. Specifically, the early detection of malignancy is an issue of great importance; in our study, five patients were diagnosed with lung cancer, cholangiocarcinoma, hepatocellular carcinoma and renal cancer. All of them had been incidentally diagnosed on CMR for the first time, and the patients' management was subsequently changed. Accordingly, specialists who interpret CMR should be trained and qualified enough to recognize and evaluate extra-cardiac pathologies. The limitations of our study are as follows. There were limited follow-up data, and a lack of histopathological verification of indeterminate incidental extracardiac findings. We might have underestimated the significance of the noncar- 



Fig. 3. A, B - Pulmonary thromboembolism (arrow) detected at CMR. In CMR of a 48-year-old woman the pulmonary thromboembolism was detected on 3-chamber view SSFP sequence. This extracardiac finding was classified as a severe extracardiac finding and changed the patient's clinical management

diac findings. Due to the retrospective design, follow-up data were not available for all patients, and it was also not known whether ECF had already been found before. Additionally, we did not perform a separate dedicated reading of the actual CMR scans and focused only on the data from an original clinic setting. Thus, the actual prevalence of ECF could be higher. More ECF, especially insignificant and minor findings, might be detected with a second reading. A cost/efficacy analysis was not performed in the present study. A prospective, controlled study is necessary to elucidate cost/efficacy of evaluating ECFs in CMR.

\section{Conclusions}

Although a small percent of the findings resulted in therapeutic consequences, some of them are clinically significant and might change a patient's diagnosis, lead to further investigations, intervention or treatment and therefore should not be dismissed, including asymptomatic malignancies, pulmonary thromboembolism or aortic dissection. The lungs, mediastinum, bones, and upper abdomen should be reviewed in all CMR studies. Physicians who analyze cardiac magnetic resonance imaging, either radiologists or cardiologists, should carefully evaluate all the organs in the scan.

\section{Disclosure}

The authors report no conflict of interest.

\section{References}

1. Bruder O, Wagner A, Lombardi M, Schwitter J, van Rossum A, Pilz G, Nothnagel D, Steen H, Petersen S, Nagel E, Prasad S, Schumm J, Greulich S, Cagnolo A, Monney P, Deluigi CC, Dill T, Frank H, Sabin G, Schneider S, Mahrholdt H. European Cardiovascular Magnetic Resonance (EuroCMR) registrymulti national results from 57 centers in 15 countries. J Cardiovasc Magn Reson 2013; 15: 9.
2. American College of Cardiology Foundation Task Force on Expert Consensus Documents, Hundley WG, Bluemke DA, Finn JP, Flamm SD, Fogel MA, Friedrich MG, Ho VB, Jerosch-Herold M, Kramer CM, Manning WJ, Patel M, Pohost GM, Stillman AE, White RD, Woodard PK. ACCF/ACR/AHA/NASCI/SCMR 2010 expert consensus document on cardiovascular magnetic resonance: a report of the American College of Cardiology Foundation Task Force on Expert Consensus Documents. J Am Coll Cardiol Elsevier Inc 2010; 55: 26142662.

3. McMurray JJ, Adamopoulos S, Anker SD, Auricchio A, Böhm M, Dickstein K, Falk V, Filippatos G, Fonseca C, Gomez-Sanchez MA, Jaarsma T, Køber L, Lip GY, Maggioni AP, Parkhomenko A, Pieske BM, Popescu BA, Rønnevik PK, Rutten FH, Schwitter J, Seferovic P, Stepinska J, Trindade PT, Voors AA, Zannad F, Zeiher A; ESC Committee for Practice Guidelines. ESC Guidelines for the diagnosis and treatment of acute and chronic heart failure 2012: The Task Force for the Diagnosis and Treatment of Acute and Chronic Heart Failure 2012 of the European Society of Cardiology. Developed in collaboration with the Heart. Eur Heart J 2012; 33: 1787-1847.

4. Kilner PJ, Geva T, Kaemmerer H, Trindade PT, Schwitter J, Webb GD. Recommendations for cardiovascular magnetic resonance in adults with congenital heart disease from the respective working groups of the European Society of Cardiology. Eur Heart J 2010; 31: 794-805.

5. Kramer CM, Barkhausen J, Flamm SD, Kim RJ, Nagel E; Society for Cardiovascular Magnetic Resonance Board of Trustees Task Force on Standardized Protocols. Standardized cardiovascular magnetic resonance protocols 2013 update. J Cardiovasc Magn Reson 2013; 15: 91-101.

6. Kirsch J, Araoz PA, Steinberg FB, Fletcher JG, McCollough CH, Williamson EE. Prevalence and significance of incidental extracardiac findings at 64-multidetector coronary CTA. J Thorac Imaging 2007; 22: 330-334.

7. Vogel-Claussen J, Li D, Carr J, Liu K, Szklo M, Lima JAC, Bluemke DA. Extracoronary abnormalities on coronary magnetic resonance angiography in the multiethnic study of atherosclerosis study: frequency and clinical significance. J Comput Assist Tomogr 2009; 33: 752-754.

8. Zimmermann S, Pistner W, Uebis R, Freund M. Relevant secondary findings in magnetic resonance imaging of the heart using the examples of a bronchial carcinoma and a malignant lymphoma. Radiologe 2007; 47: 915-918.

9. Khosa F, Romney BP, Costa DN, Rofsky NM, Manning WJ. Prevalence of noncardiac findings on clinical cardiovascular MRI. AJR Am J Roentgenol 2011 196: W380-W386.

10. Atalay MK, Prince EA, Pearson CA, Chang KJ. The prevalence and clinical significance of noncardiac findings on cardiac MRI. AJR Am J Roentgenol 2011; 196: W387-W393.

11. Khosa F, Romney BP, Costa DN, Rofsky NM, Manning WJ. Prevalence of noncardiac findings on clinical cardiovascular MRI. AJR Am J Roentgenol 2011 196: $380-386$ 